\title{
Lithuanian Literature in the Scope of Distant Reading
}

INDRE் ŽAKEVIČIENĖ

\begin{abstract}
The aim of this article is to discuss the meanings of a specific place chosen in different literary texts, using preliminary results of the research of Franco Moretti in the field of distant reading, to ponder upon the approach towards this specific location in different cultures - in literary texts of Lithuanian and American authors. The main instrument to reach the aforesaid aim is the statements of network theory which are important to the distant reading method. The main focus is on the specific kind of network ties: the so-called bridging tie, which in the network theory is considered to be a potential source of new ideas. The bridging tie connects the node/individual to somebody who is not connected to other friends of this particular node/ individual. This type of tie stipulates the possibility to generate new ideas, to widen one's horizons and to gain more information. The bridging tie allows the character to learn something new, which is not known by the members of the concrete group, who are connected with each other through strong or weak ties of state or event. Speaking about the vast number of literary texts in the context of world literature and emphasizing the number of English literary works written during the period of more than one hundred years, Moretti looks for reliable ways to summarize literary facts, and to find some consistent patterns and particular schemes to reach this almost utopian aim. The author of this article tries to find a particular consistent pattern while looking at the randomly chosen novels of Rasa Aškinytė and Ernest Hemingway and the short stories of Tomas Staniulis and Sherwood Anderson, and choosing the episodes in different bar settings. After the research there comes the conclusion that the bar is treated as a place, open to innovations; the pattern is violated in the short story of Anderson, but this exception could be explained by Anderson's intention to write the grotesque.
\end{abstract}

Keywords: distant reading, network theory, node, bridging tie, text, communication. 


\section{Introduction}

The realm of comparative studies constantly expands making its objectives more diverse and its instruments ever more various. Comparative literature is hardly an exception. Could it be that literature itself contains far more information than subjective interpretations can encompass? Could it be that similarities are more commonly found than differences in this huge literary field? These questions may not be new, but original ideas stipulated by modern technologies and achievements in social science could bring us closer to the answers we have thought impossible to find.

The aim of this article is to discuss possible means for a small literature to improve its self-esteem and to find new fields of literary research which could incorporate other sciences or fields of interest of other researchers in order to reveal as much information or knowledge as possible, and in this case comparative studies could be treated as the most convenient space. It would be useful to concentrate on two core issues which could be treated as specific pilot problems leading to further research: the first issue - Franco Moretti's proposal to switch from close reading to distant reading while paying attention to particular nets or specific ties between the characters which can be seen in and outside every text; the second - network theory and its role in literary research. The discussion of these problems could open new horizons for small literatures, rather than often seeking for equality and tolerance under the shadow of mainstream literature. Moretti's ideas suggest at least some aspects, on the basis of which we could treat our national literature without any unnecessary misgivings.

\section{The Pyramid, or the Net?}

Using preliminary results of Moretti's research in the field of distant reading we are able to define new aims and to find some new perspectives in literary studies which, at least in Lithuania, should be updated.

Distant reading [...] allows you to focus on units that are much smaller or much larger than the text: devices, themes, tropes - or genres and systems. And if, between the very small and the very large, the text itself disappears, well, it is one of those cases when one can justifiably say, less is more. If we want to understand the system in its entirety, we must accept losing something. (Moretti 2000) 
These assumptions could be a particular signal that we have reached the top of Ana Balakian's pyramid, illustrating possible aspects of comparative literary studies: "My pyramid is not a totem pole or a spiral but a structure of density; it rises on sustained craftsmanship all the way to the top, demonstrating the difference between pure mathematical abstraction and a fleshy, concrete buildup that creative expression distills to form literature." (Balakian 1995: 266) This pyramid could be understood as a specific container, encoding different facts and regularities of cultural history; it seems that Moretti has almost the same task, but quite different tools (he and his colleagues use a so-called Docuscope ${ }^{1}$ ). Various assumptions concerning the plot of a particular literary work and different ideas this work contains or reflects may be stipulated by different historical events, cultural factors or literary traditions, but the fabric of the text, the invisible nets between words or sentences appear to be in stunningly constant order; maybe these invisible aspects affect the imagination of the reader most intensely ${ }^{2}$. If so, is there any sense looking at different literary works as a particular hierarchy but not as the net of specific material manifestation (in words and sentences) of human thoughts and emotions? In other words, treating literature as a phenomenon of "multiple design", having its formal and socalled ideal (emotional, rational, sensual) level, we could grasp it as a unit, and

1 "Docuscope is essentially a smart dictionary: it consists of a list of over 200 million possible strings of English, each assigned to one of 101 functional linguistic categories called "Language Action Types" (LATs). When Docuscope "reads" a text, it does so by looking for words and strings of words that it can "recognize" - that is to say, that it can match to one of its 101 LATs. When this happens, the associated LAT is credited with one appearance. For example, since Docuscope assigns "I" and "me" to the LAT "FirstPerson", their occurrence in a text is recorded as an appearance of the LAT "FirstPerson". (Allison, Heuser et al. 2011)

2 Such assumptions may be supported by the experts in reception theory and cognitive poetics. The fields of reception theory and cognitive poetics are closely related because of the same core subject - the human mind and individual reactions to the signals literary texts send. Therefore the realm of cognitive research could be treated as one of the best spheres where literary researchers and linguists could cooperate most effectively. "Literary reading is guided, like the migrating bird, by an array of navigational markers, such as the palette of phonetic features, significant tropes, or narrative cues, and it is these that enable readers to attain their goal. Readers do not need knowledge of phonetic tone colours, or even need to be aware of their role during reading." (Miall 2001: 407) The reader and the text are the most important: therefore the main accents should be on cognitive processes, individual experiences and empirical aspects. It is clear that specific formal aspects to which the reader does not pay any attention determine the final result of the reading process. 
unique expression of humaneness itself, not being afraid of cultural scopes of one or another country.

Moretti and his colleagues speak about astonishing results of the experiment with gothic novels. Using Docuscope and the usual way of reading (Humanscope) they gained eloquent results:

[...] as Sarah Allison immediately pointed out, the gothic of Docuscope appeared to be quite different from that of "Humanscope" (as she called it): it was not the same gothic we saw. For us, that page was gothic because of the subdued terror and the archway, the ruin and apprehension and the limbs that trembled - not because of the "he" "him" "his" "had" "was" "struck the" and "heard the" which caught Docuscope's attention. Between the two approaches, there seemed to be nothing in common. Or perhaps, more precisely: nothing in common, in terms of their units of analysis; but everything in common in terms of results: whether via banditti and blood, or "uttered the" and "covered him", Humanscope and Docuscope agreed that this page belonged to the gothic, and to no other genre. (Allison, Heuser et al. 2011)

Here, the main code is a pronoun or a verb, but what codes could be found after the experiments with the novels written in other languages? If the results were the same, we may see a new era in comparative literary studies.

\section{Network Theory and Literary Text}

One way to conduct a literary research while keeping Moretti's method of distant reading and trying to encompass as wide field of literary works as possible is to use network theory. "This is a theory that studies connections within large groups of objects: the objects can be just about anything - banks, neurons, film actors, research papers, friends... - and are usually called nodes or vertices; their connections are usually called edges; and the analysis of how vertices are linked by edges has revealed many unexpected features of large systems, the most famous one being the so-called "small-world" property, or "six degrees of separation": the uncanny rapidity with which one can reach any vertex in the network from any other vertex." (Moretti 2011) Moretti transformed literary texts into particular nets, characters into nodes, and verbal communication of characters - into specific connections. Therefore, the plot turns into a "system of regions" (Moretti 2011) reflecting the hierarchy of the characters. After identifying those nets it is possible to define so-called dense zones of the plot which could be analyzed in detail by looking for some key episodes of the text. 
ŽAKEVIČIENĖ

Literary researchers could successfully use the analysis of social networks: according to Daniel Brass, "in the case of social networks, the nodes represent actors (i.e. individuals, groups, organizations). Actors can be connected on the basis of (a) similarities (same location, same membership in the same group, or similar attributes such as gender), (b) social relations (kinship, roles, affective relations such as friendship, or cognitive relations such as knows about), (c) interactions (talks with, gives advice to), or (d) flows (information); in organizational behavior research, the links typically involve some form of interaction, such as communication, or represent a more abstract connection, such as trust, friendship, or influence." (Brass 2002) A lot of attention is paid to the specific kind of network ties, the so-called bridging tie, which in the network theory is considered to be a potential source of new ideas. The bridging tie connects the node/individual to somebody who is not connected to other friends of this particular node/individual. This type of tie stipulates the possibility to generate new ideas, to widen one's horizons and to gain more information. The bridging tie in the text is like a signal that the character can learn something new which is not known by the members of the group the character is familiar with, though those members can be connected among themselves with strong or weak ties of state or event.

Moretti's ideas and the main rules of network theory used in practice could show the possibility to compare Lithuanian and American literature without any concern or worry that Lithuanian literature would seem as a tiny dot in front of this huge body of well-known masterpieces.

\section{Schematic Picture of the Bar}

The material chosen - two extracts from Lithuanian literary texts, Rasa Aškinytë's novel Lengviausias (The Easiest One, 2011) and Tomas Staniulis's short story Mažasis Kaukoles meistras (The Minor Master of the Skull, 2008), and two short extracts from American masterpieces (Ernest Hemingway's The Sun Also Rises (1926) and Sherwood Anderson's short story The Egg (1920)), which were written in different literary epochs, are of different literary value and different stylistic features, but considering the network theory and an attempt to apply it on literary works, such differences are not important, because we focus on a particular formal (in the full sense of word) level of literature. The aim of such formal analysis is to compare Lithuanian and American schemes which could be extracted from the episodes chosen. 
The story of Lengviausias takes place in a bar called Prancūzija. In this extract there are a number of characters who are not so important - they appear periodically and some of them do not appear at all:

Fat lady in her red dress used to come here every day; she used to drink only beer and used to leave in twilight. [...] One fellow with white hair, in his checked jeans, curly girl. [...] A gentleman in checked skirt, with glasses and stupid face. Another white-haired gentleman with long moustache, looking like a seal. [...] A lot of lonely people used to come at Prancūzija, but they never communicated. [...] It was for the sixteenth time when I've brought some drinks not for the right person, not for the one, for whom Greek has ordered. [...] Alex entered the bar. [...] Alex looked up at me. (Aškinytè 2011: 84-86)

In the following, we define some links connecting the characters or the nodes. The scheme in Figure 1 illustrates the characters connected with the links based on social relations and interactions. The narrator "I" is a friend of Aleksas and Lady in Red. She is a waitress in the bar owned by a Greek. The group of her acquaintances (Lady in Red, Greek and Aleksas) is linked with other six characters with the bridging tie through the narrator. This dense zone of the net should be treated as a particular space inspiring potential innovative ideas, because the subordinate characters are not linked with each other but in various ways communicate with the waitress (the narrator), so they set up productive bridging ties as well.

\section{The bar Prancūzija}

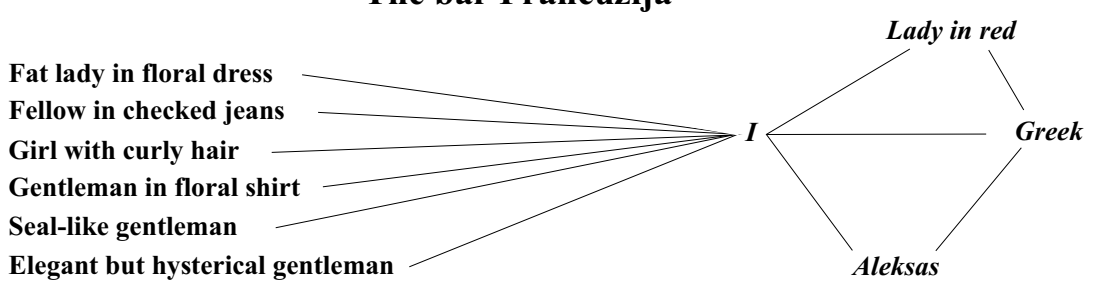

Fig. 1 
ŽAKEVIČIENĖ

In Staniulis's short story Mažasis kaukolès meistras, various events which are important to the main characters take place in the bar Draugyste (Friendship):

We went to Draugyste to celebrate the end of the summer and to discuss such wonderful news. Jonas set himself behind the bar and turned up the music for those dancing wildly and sending sweet glances at our [the narrator's and Salomeja's] direction. [...] Jonas was clasped by Russians [...] We returned to our table and were waiting for Jonas; his last customers wanted to pay... (Staniulis 2008: 103-10).

In this episode, the group of active characters (the customers and the Russians) is not defined concretely. Therefore, it is not clear if it is bigger than that found in the bar Prancūzija, but this information is not significant because the main task is to determine the type of ties of the network highlighted in the text. Figure 2 illustrates the relations of the characters, linked together on the base of communication between the narrator "I", Salomejja and Jonas, who are friends. Jonas is a barman and the imaginable node he embodies is linked with other customers and the more generalized group - Russians, who are also the customers, but do not communicate with others. The conclusion of this modest schematic analysis is the same as in the previous novel: the bar could be treated as a distinctive perspective place, stipulating the rise of bridging ties (the barman Jonas could be treated as a bridging tie).

\section{The Bar Draugystė}

\section{Salomëja}

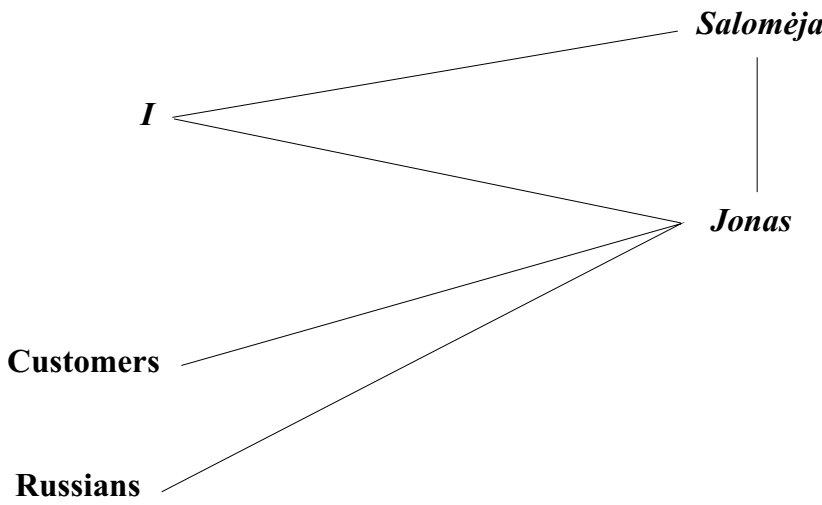

Fig. 2 
The characters of Hemingway's The Sun Also Rises rarely leave the bars, therefore the occasionally chosen episode can be discussed as representing other similar episodes in various bars or cafés. The type of the net visible in the story is very much the same as in Staniulis' short story:

We ate dinner at Madame Lecomte's restaurant on the far side of the island. It was crowded with Americans and we had to stand up and wait for a place. Someone had put it in the American Women's Club list as a quaint restaurant on the Paris quais as yet untouched by Americans, so we had to wait forty-five minutes for a table. Bill had eaten at the restaurant in 1918, and right after the armistice, and Madame Lecomte made a great fuss over seeing him. (Hemingway 1954: 76)

The narrator Jake and his friend Bill are linked on the basis of communication, and Madame Lecomte, whose role is not significant, is linked with the narrator's friend by the bridging tie (Jake does not know Madame Lecomte). The Americans should also be linked with Madame Lecomte but neither do they communicate with Bill nor Jake. So in this story, the restaurant appears as an auspicious place for bridging ties to form and could be regarded as a congenial space for useful deals or promising projects.

\section{Madame Lecomte's restaurant}

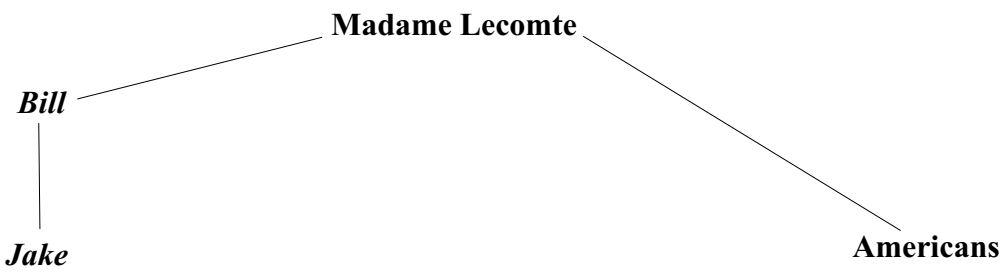

Fig. 3

Another interesting example is seen in The Egg by Sherwood Anderson. In this short story, it does not justify one's expectations but breaks the rule of the previous examples. We can discern the only weak link based on the event (fig. 4):

For a long time father, whom Joe Kane had never seen before, remained silently gazing at his visitor. He was no doubt suffering from an attack of stage fright. [...] Grabbing another egg from the basket on the counter, he threw it, just missing the head of the young man as he dodged through the door and escaped. (Anderson 1920) 


\section{Restaurant in Bidwell}

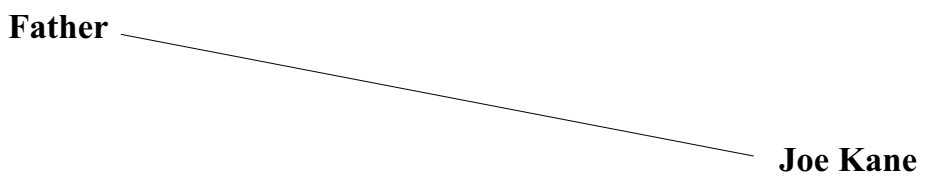

Fig. 4

The analysis of random episodes shows particular regularity - the bar could be treated as a place open to innovations, but in Anderson's case this regularity could be violated because of one simple reason which could even confirm the presumptions about appropriate codes of the bar: Anderson creates the grotesque by consciously distorting usual forms of everyday life while dismantling imaginable nets. This exception does not deny the code of the bar (the bar as a place for useful deals and future projects to appear), because at the beginning of the story there are references to another bar and those references give rise to the allusions to virtual nets which are very much like those mentioned above - the character who has decided to open his own bar used to frequent various pubs in his young days:

He had then a horse of his own and on Saturday evenings drove into town to spend a few hours in social intercourse with other farmhands. In town he drank several glasses of beer and stood about in Ben Head's saloon - crowded on Saturday evenings with visiting farmhands. Songs were sung and glasses thumped on the bar. (Anderson 1920)

So trying to make a scheme of this episode we should mark at least two links connecting "him", "other farmhands" and the barman, without whom there were no "glasses thumped on the bar". It means that there would be particular conditions for bridging link to form.

What is the use of such schematic analysis and in what ways does it enrich the knowledge about literary work or the context of literature in general? At present, it is difficult to say, but that the text is read "formally" or "at a distance" obviously gives the same information as in the conclusion made after consistent research. For example, in the interdisciplinary international scientific conference in Šiauliai in 2012, literary researcher Žydronè Kolevinskienè presented her paper on the saloons in the United States at the beginning of the 20th century and their role on the everyday life of Lithuanian emigrants. She concluded that pubs or saloons were the main places for the emigrants' 
meetings, and for new deals and bargains to be made, respectively. Purely schematic and formal analysis (even without paying attention to the meaning of the text) reveals general knowledge about human habits, needs or imaginable chances. Could those schemes be treated as unseen but reliable bases of literary texts, and if so, could they be equivalent to the base of Balakian's pyramid - the former primordial unity stipulated by myth?

\section{Final Remarks}

After this pilot analysis we conclude that the network theory could serve in specific literary research as a purely formal method - registering the characters who communicate and defining the links set between them - which does not require close reading or accurate notation of subjective reactions, yet clearly and successfully decodes separate episodes of the text and helps to view its structure or specific dense zones - episodes where there are a lot of ties and nodes - which could be the most or the least important depending on the characteristics of the links defined in the text. Such a formal viewpoint shows that generalities are better than the subjective method of close reading because they allow us to grasp the meaning of the text and encourage us to analyze different allusions objectively. The instrument of distant reading helps to view a text more widely, and after grasping the entirety e.g. the text of a short story, a novel or a play, the context of a concrete literary period, the field which several literary texts belong to (subject to the aims), it would be easier to summarize or to go deeply into separate segments of the net.

It is obvious that modern literary studies require different means for gaining results and it is not enough to stay purely at the textual level. Laboratory findings are as important as the capacity of the researchers to get solid insights and well-founded assumptions with some books at hand. Specific interdisciplinary theories could be regarded as nice examples of multidimensional attitudes towards literature and human abilities, and as interesting perspectives for the researchers aspiring to concrete answers and inspiring conclusions.

Indrè Žakevičienè

i.zakeviciene@hmf.vdu.lt

Vytauto Didžiojo universitetas

Lietuvių literatūros katedra

K. Donelaičio g. 52

LT-44248 Kaunas

LIETUVA 
ŽAKEVIČIENĖ

\section{Bibliography}

Allison, S., Heuser, R., Jockers, M., Moretti, F., Witmore, M. 2011. Quantitative Formalism: an Experiment. - Literary Lab, Pamphlet 1, January 15. - http://www. litlab.stanford.edu (27.08.12).

Anderson, S. 1920. The Egg. - http://www.eldritchpress.org/tales/egg.html (06.01.14).

Aškinytė, R. 2011. Lengviausias. Vilnius: Vaga.

Balakian, A. 1995. Theorizing Comparison: The Pyramid of Similitude and Difference. - World Literature Today, 2, 263-267.

Brass, D. J. 2011. A Social Network Perspective on Industrial/Organisational Psychology. - http://www.linkscenter.org/papers/IOHandbook.pdf (28.01.14).

Ginzburg, C. 1989. Clues, Myths, and the Historical Method. Baltimore: John Hopkins UP.

Granovetter, M. 1973.The strength of weak ties. - American Journal of Sociology, $78(6), 1360-1380$.

Hemingway, E. 1954. The Sun Also Rises. New York: Charles Scribner's Sons.

Miall, D. S. 2001. An Evolutionary Framework for Literary Reading. - D. Schram, G. Steen, eds., The Psychology and Sociology of Literature, John Benjamins Publishing, 407-419.

Moretti, F. 2000. Conjectures on World Literature. - http://www.newleftreview.org/ A2094 (28.01.12).

Moretti, F. 2011. Network Theory, Plot Analysis. - Literary Lab, Pamphlet 2, May 1. http://litlab.stanford.edu (27.08.12).

Staniulis, T. 2008. Diena, kurią verkiau visą. Vilnius: Versus aureus. 